\title{
The Readiness of Natural Science Secondary School Teachers in Distance Learning during the Covid-19 Pandemic
}

\author{
Nur Efendi ${ }^{\mathrm{a}}$, Septi Budi Sartika ${ }^{\mathrm{b} *}$, Noly Shofiyah ${ }^{\mathrm{c}}$ \\ ${ }^{a}$ Science Education Study Program, Faculty of Psychology and Educational Sciences, Universitas Muhammadiyah Sidoarjo, Indonesia \\ ${ }^{\mathrm{b}}$ Science Education Study Program, Faculty of Psychology and Educational Sciences, Universitas Muhammadiyah Sidoarjo, Indonesia \\ ${ }^{\mathrm{c}}$ Science Education Study Program, Faculty of Psychology and Educational Sciences, Universitas Muhammadiyah Sidoarjo, Indonesia
}

*Corresponding author: Jalan Mojopahit 666 B Sidoarjo, Jawa Timur. 61215, Indonesia. E-mail addresses: septibudi1@umsida.ac.id

\section{a r t i c l e i n f o}

Article history:

Received: 21 September 2020

Received in revised form: 12

December 2020

Accepted: 29 December 2020

Available online: 31 December 2020

Keywords:

Covid-19 pandemic

Distance learning

Secondary school

Natural science's teacher

Readiness

\section{a b $\mathbf{s} \mathbf{t} \mathbf{r} \mathbf{a} \mathbf{t}$}

\begin{abstract}
The purpose of the research is to describe the readiness of secondary school teachers in East Java in distance learning during the covid-19 pandemic and the teachers' efforts in East Java in learning during the covid-19 pandemic. The research method was survey research with a sample of 70 secondary schools of natural science teachers in East Java. The data was collected by distributing questionnaires with a Likert scale. The collected data was then analyzed using descriptive statistics with Aydin \& Tasci model. The results showed that secondary school science teachers in East Java were ready for distance learning, with a score of 3.45 and performing distance learning using the Google Classroom app with a percentage of $71.8 \%$ during the covid-19 pandemic. To face distance learning obstacles, the teachers can create modules for all topics of natural science at secondary school. The created module can be uploaded on an e-learning platform or WhatsApp Group. Besides, to minimize internet network use and the lack of communication tools, offline learning can be conducted, especially for natural science learning through a practicum. Furthermore, these results can be used as the basis for developing teacher resources through the enrichment of teaching models and strategies that can be applied under any circumstances in the event of a pandemic.
\end{abstract}

2020 Scientiae Educatia: Jurnal Pendidikan Sains

\section{Introduction}

Natural Sciences is a branch of science that learns about natural phenomena (Carin \& Sund, 1993; Trianto, 2012; Aji, 2017). Natural science learning in secondary school aims to 1) can foster students' confidence that they are "capable" in science and that natural science is not a lesson to be feared; 2) teaching natural science not only to teach its concepts but also to the development of scientific attitudes and skills (the domain of knowledge and cognitive processes); 3) natural science learning provides a learning experience that develops reasoning, planning and conducting scientific investigations, using the knowledge already learned to understand the symptoms of nature occurring around it; and 4) revitalize science process skills for students, teachers, and prospective teachers as the primary mission of the teaching and learning process of science in schools to develop skills observation, planning investigation, interpreting data and information (narration, images, charts, tables) and drawing conclusions (Kemdikbud RI, 2013). In the current condition, natural science learning requires students to 
have a learning experience that develops reasoning skills, planning and conducting scientific investigations, using the knowledge studied to understand the symptoms of nature that occur around it.

Natural Science is one of the compulsory subjects in school. During the covid-19 pandemic, natural science learning is also not missed online or offline. Whereas in science learning, in addition to teaching theory, also practice practicum. One of the education policies during the Covid-19 pandemic is about implementing Circular Letter 3 of 2020 on The Prevention of Covid-19 in the education unit, "We encourage teachers not to complete all materials in the curriculum. The most important thing is that students are still involved in relevant learning such as life skills, health, and empathy, said Minister of Education Nadhim Makarim. This policy is in line with the Ministry of Education's learning scenario from home until the end of 2020. Learning activities are carried out from their homes; both teachers and students do not have to complete all materials in the curriculum but involve learning relevant to hard skills and soft skills.

Learning from home is done online, and offline raises many problems for various parties, teachers, students, and parents. This is because online learning is used with various considerations concerning the condition of teachers and learners (Jamaluddin et al., 2020). However, online and offline learning is a solution to prevent the transmission of Covid-19. This learning applies to all subjects, including science. Science learning during the Covid-19 pandemic in Indonesia, it can be stated that the infrastructure readiness factor is a good category, but the factors of teachers, students, and parents are still not good in distance learning. This is in line with the results of Churiyah et al. (2020), Indonesia has prepared an excellent virtual infrastructure, but teachers and school factors still need to understand more about the essence of distance learning. Students have low self-learning, so they are less able to manage distance learning activities, teachers tend to stutter about technology, and parents do not understand the nature of teaching and learning activities carried out at home. Purwanto et al. (2020), there are some obstacles experienced by students, teachers, and parents in online teaching and learning activities, namely the mastery of technology is still lacking, the addition of internet quota costs, the existence of additional work for parents in assisting children in learning, communication and socialization between students, teachers and parents are reduced and working hours become unabated for teachers because they have to communicate and coordinate with parents, other teachers, and principals. 
This is also in line with the learning that occurred in other countries, the results of the Ionescu et al. (2020) research although before the pandemic the e-learning system in Romania was rarely used by students and teachers, the results showed that students had received online learning, even if they felt less attractive than the traditional education system. From a teacherstudent-parent perspective, e-learning is an effective continuous learning solution in current and future conditions but requires good collaboration between parents and teachers, careful monitoring of children/students' behavior to identify and combat effects that may be determined by changes in learning, and social reality.

According to Diah (2013), students' readiness will respond to the situation in its way, and readiness is the overall condition of a person who makes him ready to give a response or answer. Based on several theoretical and empirical studies, it can be stated that distance learning both online and offline is an effective solution in the Covid-19 pandemic conditions. However, it should be noted that there are several factors, including infrastructure, teachers, students, and parents, so that distance learning can be said to be effective. This research will describe the readiness of natural science teachers in East Java in distance learning and the obstacles faced by teachers in the pandemic Covid-19 period.

\section{Method}

This study uses quantitative research on this type of survey. Surveys are studies aimed at decrypting the characteristics of a population (Fraenkel et al., 2012). The survey used in this study is trends studies, which are different samples from the same population over time to examine the development of characteristics. The sample in this study amounted to 70 science teachers in East Java who were randomly taken. The study used a questionnaire containing 26 questions. Questions based on the So \& Swatman (2006) for 6 (six) factors are (1) student readiness, (2) teacher readiness, (3) infrastructure, (4) management support, (5) school culture, and (6) trends in face-to-face learning. In addition to questionnaires, the study also used structured interviews with 3 question items to dig into data about the constraints and e-learning platforms used.

To analyze the questionnaire results' data, the readiness tool was used by Aydin \& Tasci (2005) or better known as E-Learning Readiness (ELR). Based on the scoring scale in Figure 1 , readiness is stated, starting at a score of 3.4, while a score below 3.4 can be categorized as 
not ready. The total score for each question item on the next questionnaire is calculated on average, and scores obtained are further interpreted using the following assessment scales:

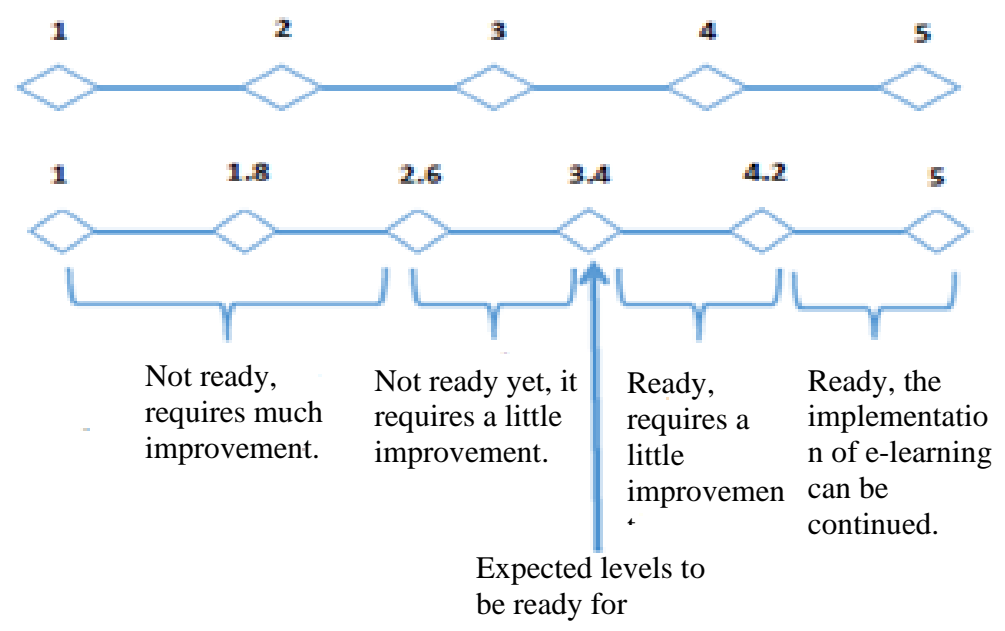

Figure 1. Assessment Scale (Aydin \& Tasci, 2005)

\section{Result and Discussion}

The readiness of secondary school teacher's in East Java to implementing distance

\section{learning.}

Data in the form of poll results obtained from respondents as many as 70 teachers then analyzed using ELR Aydin \& Tasci (2005) model. The poll uses the Likert scale. The poll had 26 questions with alternative "Strongly Agree" answers with a score of 5, "Agree" with a score of 4, "Neutral" with a score of 3, "Disagree" with a score of 2, and "Strongly Disagree" with a score of 1 . The purpose of using questionnaires in this study is to describe the level of readiness of science teachers in the application of e-learning.

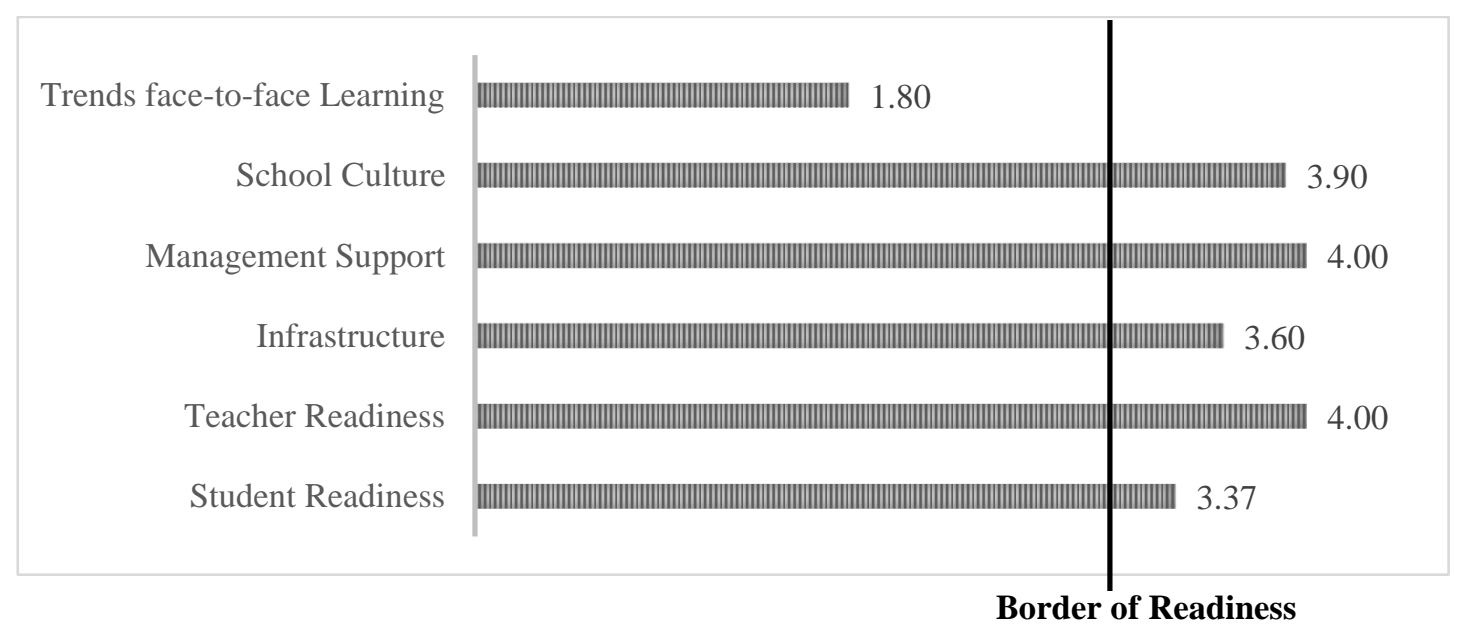

Figure 2. Graph of ELR natural science teacher's of secondary school score in East Java 
Based on the graph presented in Figure 2, it is known that of the six readiness factors, there are four factors that are stated to be ready and two factors that are not yet ready. The four factors stated to be ready include teacher readiness, infrastructure, management support, and school culture, while the two factors stated to be unprepared are the readiness of students and trends in face-to-face learning.

Students' readiness for e-learning in natural science learning has an ELR score of 3.37, which indicates the learner is not ready and needs a little improvement. Improving students' knowledge can be done by socializing or briefing students on e-learning or online learning. Parents' support for the implementation of e-learning at home, students' ability to manage time during e-learning, the ability of students to access e-learning has not reached the ready category.

Learner readiness is indispensable in e-learning. Therefore, all aspects of the learner are essential to note in maintaining and improving the quality of learning. Knowing students' readiness is expected to improve learning outcomes, so an increase in these factors is needed to optimize the implementation of e-learning. For other factors, such as teacher readiness, infrastructure, management support, and school culture, all of these factors get an ELR score above 3.4 , indicating that it is ready but requires a slight improvement.

A very different thing is indicated by factor 6 , which is the tendency of face-to-face learning. The lowest ELR score was 1.8. This shows that both teachers and learners are not ready for elearning and need much improvement because they still choose face-to-face learning. Teachers and learners' tendency to do face-to-face learning is because they face some obstacles in implementing e-learning in this pandemic period. These obstacles include 1) the motivation of learning students to study independently during the Covid-19 pandemic is still low; unstable internet network, which occurs in students living in rural areas; 3 ) not all students or parents of students have high information technology-based communion tools, which is due to the low level of financial ability of students; and 4) the ability of information technology students in using the e-learning platform is still lacking. This is because, during this time, science learning is accustomed to face-to-face, where teachers only use teaching textbooks as the primary source of learner learning.

The results are quite relevant to his research Waryanto, and Insani (2013) that the category that has a high e-learning readiness score is the category of sociological readiness, namely ELR score that is included in the category of ready is sociological readiness, environmental 
readiness, human resource readiness, technological readiness, and content readiness. Hariyadi et al. (2013), the school factor positively affects teacher readiness; this indicates that the school's support and policies are beneficial to the teacher's readiness in using e-learning. It is also in line with the results of Ichsan et al. (2020) that e-learning has not gone entirely and needs to be improved, constraints when e-learning is done need to be overcome and needs to be innovated by teachers in the form of teaching materials development, learning media and also Student Worksheets. Thus, it can be stated that several factors also affect teachers' readiness in online learning by using e-learning, especially in the period of a Covid-19 pandemic.

This is in line with Fauzi and Khusuma (2020) research results that the teachers understand the context of online learning. However, implementation in various problems found 1) availability of facilities, 2) use of the network and internet, 3) planning, implementation, and evaluation of learning and 4) collaboration with parents. Online learning helps teachers during the Covid-19 pandemic but is considered ineffective, even $80 \%$ of teachers are dissatisfied through online learning. The results of Rasmitadila's analysis (2020) found four main aspects, namely instructional strategies, challenges, support, and teacher motivation, contributions to online collaborative learning literature between teachers, parents, and schools that impact student success.

\section{The efforts of natural science teacher's of secondary school in East Java at learning during the Covid-19 pandemic}

Based on interviews with science teachers about efforts made to conduct learning during the Covid-19 pandemic, teachers say they have implemented online learning where the most widely used e-learning platform is Google Classroom (Figure 3). 


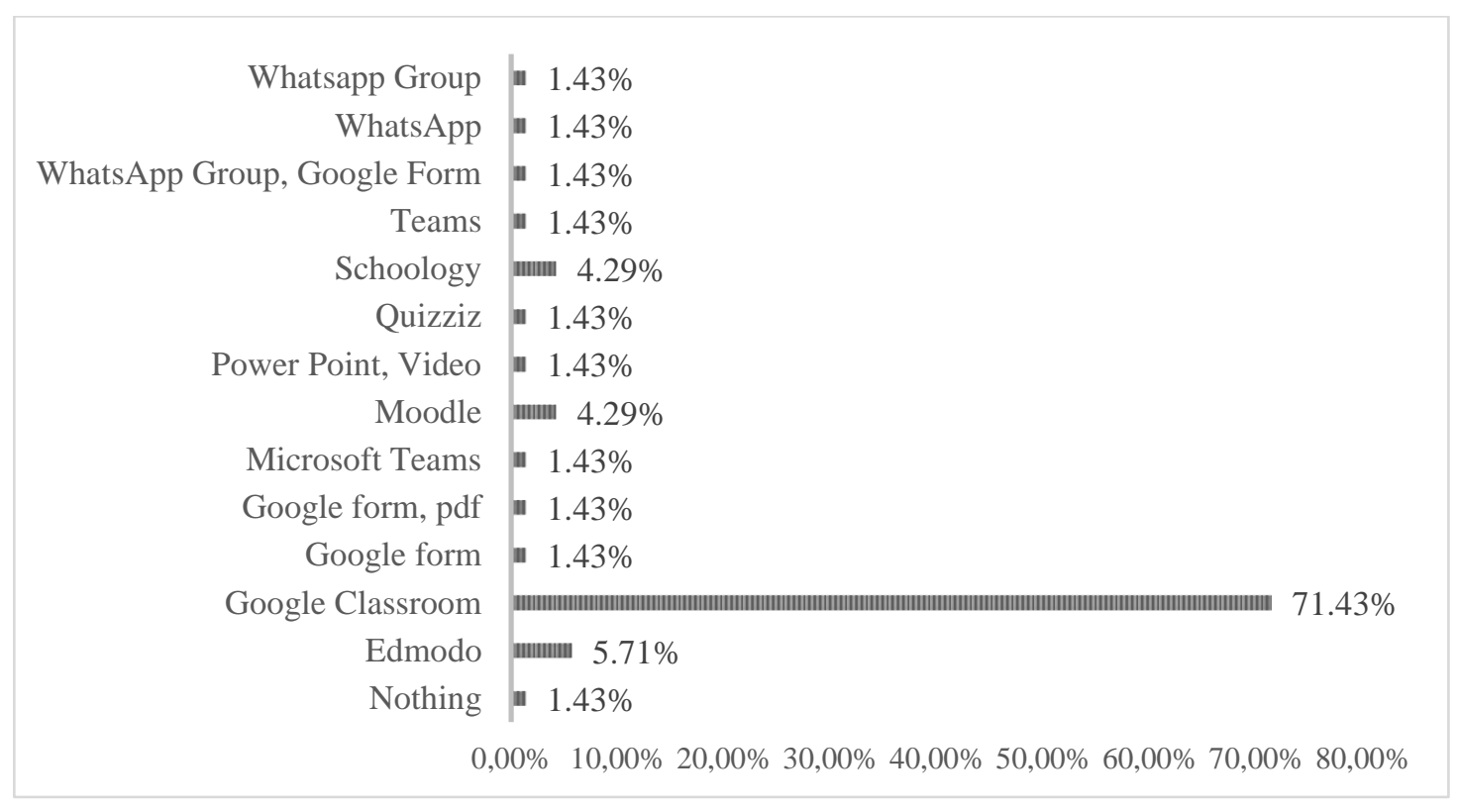

Figure 3. Use of the E-Learning Platform

Figure 3 explains that in addition to Google Classroom, science teachers in East Java also use Moodle, Schoology, Quizizz, Microsoft Term, Edmodo, and WhatsApp Groups. The application of e-learning during the Covid-19 pandemic goes well if teachers' and learners' tendency towards face-to-face learning is changed. The tendency towards face-to-face learning provides an early look at the difficulties and difficulties in using e-learning because teachers and learners are accustomed to using face-to-face learning.

The results are relevant to Albab (2020), the constraints of online learning (e-learning) in the form of internet connection, internet quota, devices used, and material understanding. Faslah and Santoso (2017), there needs to be organizing and evaluation training based on elearning, management of resources for budget, improvement of laboratory facilities and infrastructure, improvement of internet facilities, adjustment of curriculum and training for educational personnel in the management of e-learning. Agustiani (2019), the constraints of the use of e-learning are $20 \%$ of students' ability, $60 \%$ internet network and student ability, and $20 \%$ of teacher facilities and abilities.

To change that view, teachers can participate in several pieces of training or workshops on e-learning or media creation for online learning, while students can continue to be motivated by teachers by presenting online natural science lessons that appeal to students. To overcome the constraints of internet networks can be done offline learning, where the mechanism of implementation must also be prepared well by teachers, so it is most likely that science learning will run offline or online. 
This result is in line with Chung et al. (2020) that most respondents prefer online learning through prerecorded lectures uploaded to Google Classroom and YouTube. Nevertheless, Alqahtani and Ajkhan (2020) found that technology management, support from management, increased awareness of students to use e-learning systems, and demanding a high level of information technology from instructors, students, and universities are the most influential factors for e-learning during Covid-19, the most suitable practice is blended learning which is a combination of online and offline.

\section{Conclusion}

Based on the results of research and discussion, it can be concluded that: 1) natural science teachers in East Java secondary school have an ELR score of 3.45 with categories ready in the application of e-learning but require a slight improvement on several factors; 2) natural science learning conducted during the Covid-19 pandemic, teachers have used e-learning with the most Google Classroom platform. To face the obstacles of using e-learning, teachers can produce teaching materials such as modules or students' worksheets. The modules or student worksheets can then be distributed to students through the e-learning platform or WhatsApp Group. Besides, to minimize internet network use and the absence of communication tools, offline learning can be done, especially for natural science learning through the practicum. These results study can be used by the teachers who will develop the science learning resources, teaching strategies of distance learning that can be implemented under any circumstances.

\section{Acknowledgements}

The author thanked all parties contributing to this research, namely the East Java Education Quality Assurance Institute and natural science teachers in East Java.

\section{References}

Agustiani, E. (2019). Kendala-kendala guru fisika dalam pemanfaatan sumber belajar elearning pada SMA Negeri Se-Kota Banda Aceh. Thesis ETD Unsyiah. Retrieved from https://etd.unsyiah.ac.id/index.php?p=show_detail\&id=63392

Aji, S. D. (2017). Etnosains dalam membentuk kemampuan berpikir kritis dan kerja ilmiah siswa. In Prosiding SNPF (Seminar Nasional Pendidikan Fisika) (pp. 7-11).

Albab, S. U. (2020). Analisis kendala pembelajaran e-learning pada era disrupsi di SMK Terpadu Al-Islahiyah Singosari Malang. Mudir: Jurnal Manajemen Pendidikan, 2(1), 4657. 
Alqahtani, A. Y., \& Rajkhan, A. A. (2020). E-learning critical success factors during the Covid19 pandemic: A comprehensive analysis of e-learning managerial perspectives. Education Sciences, 10(9), 1-16.

Aydin, C. H., \& Tasci, D. (2005). Measuring readiness for e-learning: Reflections from an emerging country. Journal of Educational Technology \& Society, 8(4), 244-257.

Carin, A. A., \& Sund, R. B. (1993). Teaching modern science. Merrill.

Chung, E., Subramaniam, G., \& Dass, L. C. (2020). Online Learning Readiness among University Students in Malaysia amidst COVID-19. Asian Journal of University Education, 16(2), 46-58.

Churiyah, M., Sholikhan, S., Filianti, F., \& Sakdiyyah, D. A. (2020). Indonesia education readiness conducting distance learning in Covid-19 pandemic situation. International Journal of Multicultural and Multireligious Understanding, 7(6), 491-507.

Diah, L. (2013). Belajar dan Faktor-Faktor yang Mempengaruhinya. PT. Rineka Cipta.

Faslah, R., \& Santoso, H. B. (2017). Analisis kesiapan implementasi e-learning menggunakan e-learning readiness model. POSITIF: Jurnal Sistem dan Teknologi Informasi, 3(2), 113120.

Fauzi, I., \& Khusuma, I. H. S. (2020). Teachers' elementary school in online learning of COVID-19 pandemic conditions. Jurnal Iqra': Kajian Ilmu Pendidikan, 5(1), 58-70.

Fraenkel, J. R., Wallen, N. E., \& Hyun, H. H. (2012). Internal validity: How to design and evaluate research in education. McGraw-Hill.

Hariyadi, F. K. N., Muqtadiroh, F. A., Kom, S., Nisafani, M. A. S., \& Kom, S. (2013). Analisis hubungan faktor masyarakat, sekolah, dan guru terhadap kesiapan guru dalam menggunakan e-learning pada pendidikan tingkat menengah (Studi Kasus: SMPN 1 Jember) (Doctoral dissertation, Institut Teknology Sepuluh Nopember).

Ichsan, I. Z., Rahmayanti, H., Purwanto, A., Sigit, D. V., Kurniawan, E., Dewi, A. K. \& Marhento, G. (2020). Covid-19 dan e-learning: Perubahan strategi pembelajaran sains dan lingkungan di SMP. JINoP (Jurnal Inovasi Pembelajaran), 6(1), 50-61.

Ionescu, C. A., Paschia, L., Gudanescu Nicolau, N. L., Stanescu, S. G., Neacsu Stancescu, V. M., Coman, M. D., \& Uzlau, M. C. (2020). Sustainability Analysis of the e-learning education system during the pandemic period-COVID-19 in Romania. Sustainability, 12(21), 9030.

Jamaluddin, D., Ratnasih, T., Gunawan, H., \& Paujiah, E. (2020). Pembelajaran daring masa pandemik Covid-19 pada calon guru: hambatan, solusi dan proyeksi. LP2M UIN Sunan Gunung Djati Bandung. Retrieved from http://digilib.uinsgd.ac.id/30518/

Kemdikbud, R. I. (2013). Pedoman diklat guru dalam rangka implementasi kurikulum 2013. Kementerian Pendidikan dan Kebudayaan RI.

Purwanto, A., Pramono, R., Asbari, M., Hyun, C. C., Wijayanti, L. M., \& Putri, R. S. (2020). Studi eksploratif dampak pandemi COVID-19 terhadap proses pembelajaran online di sekolah dasar. EduPsyCouns: Journal of Education, Psychology and Counseling, 2(1), 1-12.

Rasmitadila, R., Widyasari, W., Humaira, M., Tambunan, A., Rachmadtullah, R., \& Samsudin, A. (2020). Using blended learning approach (BLA) in inclusive education course: A study investigating teacher students' perception. International Journal of Emerging Technologies in Learning (IJET), 15(2), 72-85. 
So, T., \& Swatman, P. M. (2006). e-Learning readiness of Hong Kong Teachers. University of South Australia.

Trianto. (2012). Model pembelajaran terpadu. Bumi Aksara.

Waryanto, N. H., \& Insani, N. (2013). Tingkat kesiapan (readiness) implementasi e-learning di sekolah menengah atas kota Yogyakarta. Jurnal Pendidikan Matematika dan Sains, 1(2), 117-124. 